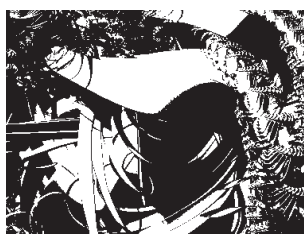

\title{
KONSTRUKCIJA UPITNIKA ZA PROCJENU PERCIPIRANE LEGITIMNOSTI NESPORTSKOGA PONAŠANJA
}

Zrinka GREBLO, Igor GRUIĆ, Katarina OHNJEC, Ivan SEGEDI, Želiko PEDIŠIĆ Kineziološki fakultet, Zagreb

UDK: 303.622:796.06

Izvorni znanstveni rad

Primlieno: 1. 10. 2009

Cili rada bio je konstruirati upitnik za procjenu percipirane legitimnosti nesportskoga ponašanja, utvrditi njegove mjerne karakteristike i provjeriti teorijske pretpostavke o relacijama percipirane legitimnosti nesportskog ponašanja sa spolom, sportskim stažem i rangom natjecanja. Konstruirani upitnik sadrži 14 čestica, koje opisuju specifična nesportska ponašanja iz kategorija fizičke agresije, verbalne agresije i varanja. Stupanj percipirane legitimnosti nesportskoga ponašanja može se interpretirati analizom odgovora na pojedine čestice upitnika, rezultatima na podskalama Legitimnost težih prekršaja, Legitimnost lakših prekršaja i Legitimnost verbalne agresije ili ukupnim rezultatom. Mierna svojstva upitnika utvrđena su na uzorku od 251 studenta Kineziološkoga fakulteta u Zagrebu. Komponentnim modelom faktorske analize, pri čemu je primijenjen Guttman-Kaiserov kriterii za redukciju broja glavnih komponenata i oblimin rotacija s Kaiserovom normalizacijom, utvrđena je jednostavna i semantički interpretabilna faktorska struktura. Cronbachov koeficijent pouzdanosti kretao se od 0,77 do 0,86 , a test-retest pouzdanosti od 0,67 do 0,85. Serijom multiplih regresijskih analiza utvrđena je različita povezanost spola, sportskoga staža i ranga natjecanja s pojedinim podskalama upitnika. Rezultati istraživanja pokazuju da konstruirani upitnik ima zadovoljavajuća mjerna svojstva te da se može rabiti za procjenu percipirane legitimnosti težih prekršaja, lakših prekršaja i verbalne agresije u sportu.

Ključne riječi: nesportsko ponašanje, sport, agresivnost, varanje Horvaćanski zavoi 15, 10000 Zagreb, Hrvatska. 
Aktivno sudjelovanje u sportskim aktivnostima važan je čimbenik psihosocijalnoga razvoja djece i adolescenata (Đonlić i sur., 2005.), stoga ne iznenađuje podatak prema kojem je u zadnja dva desetljeća naglo porastao broj istraživanja koja ispituju karakteristike moralnoga rasuđivanja sportaša (Miller i sur., 2005.). Agresivne reakcije sportaša, nepoštivanje pravila i varanje prisutni su na svim razinama sportskih natjecanja od vrhunskoga sporta do rekreativnih liga. U želji da postignu što bolje rezultate sportaši se često dovode do krajnjih granica mogućnosti (Reynolds, 2000.) te uzimaju nedopuštene stimulanse koji mogu ozbiljno narušiti psihičko i fizičko zdravlje (Holt i sur., 2009.). Rezultati nedavno provedenog istraživanja na populaciji hrvatskih sportaša pokazali su da je, pod snažnim imperativom pobjede, zastupljenost verbalnoga i fizičkoga nasilja među sportašima porasla do zabrinjavajuće razine (Greblo i sur., 2007.). Zbog svega navedenog sve se češće postavlja pitanje: "Postaje li nesportsko ponašanje normativ u sportu?"

Teorijska razmatranja i empirijski radovi o utjecajima sportske aktivnosti na razvoj ličnosti još nisu rezultirala jednoznačnim zaključcima (Horga, 1993.). U skladu s navedenim, u literaturi se mogu naći razna teorijska stajališta, prema kojima aktivno sudjelovanje $\mathrm{u}$ sportu može ostvariti pozitivan, neutralan ili negativan utjecaj na moralno rasuđivanje pojedinca. Prema prvom teorijskom pravcu, sudjelovanje u sportskim aktivnostima dovodi do poželjnih socijalnih i moralnih ishoda, što je osobito izraženo u timskim sportovima (Evans i Roberts, 1987.; Fox, 1988.). Pretpostavlja se da suradnja s članovima momčadi prilikom postizanja zajedničkoga cilja promiče važnost pridržavanja pravila te pridonosi razvoju socijalnih vještina, suradnje, tolerancije i međusobnoga razumijevanja te da na taj način usvojene vrijednosti pojedinci primjenjuju i izvan sportskoga konteksta. U prilog navedenom govore i rezultati istraživanja kojima je utvrđena negativna povezanost između sudjelovanja u sportu i delinkvencije (Hastad i sur., 1984.; Segrave i sur., 1985.). Drugo teorijsko stajalište, koje zagovara hipotezu o neutralnom djelovanju sportske aktivnosti na razvoj ličnosti pojedinca, promatra sport kao oblik igre koji je izdvojen iz "stvarnoga svijeta". U tom kontekstu, pridržavanje ili kršenje normi i pravila, usvajanje poželjnih ili nepoželjnih vrijednosti ostaje na razini igre i ne odražava se na moralno rezoniranje sportaša u širem smislu (Arnold, 1994.). Konačno, dio empirijskih nalaza govori u prilog hipotezi o nepoželjnim učincima sportske aktivnosti na moralno rezoniranje izvan sportskog okruženja. Prema rezultatima longitudinalnog istraživanja Begga i sur. (1996.), uključenost u indi- 
DRUŠ. ISTRAŽ. ZAGREB GOD. 20 (2011), BR. $3(113)$

STR. $771-792$

GREBLO, Z. I SUR.: KONSTRUKCIJA... vidualni (ali ne i u timski) sport povezana je s mladenačkom delinkvencijom. Na mogući nepoželjan utjecaj bavljenja sportskom aktivnošću među prvima su upozorili Ogilvie i Tutko (1971.) u članku pod nazivom "Sport: ako želite izgraditi karakter, pokušajte nešto drugo". Navedeni rad potaknuo je niz istraživanja o mogućim negativnim utjecajima bavljenja sportom na razvoj ličnosti i moralnoga rasuđivanja. Rezultati empirijskih istraživanja pokazali su da je nesportsko ponašanje, poput varanja i agresivnosti, relativno učestalo u sportskom okruženju te da uspješne sportaše često karakteriziraju osobine poput dominantnosti, asertivnosti, distanciranosti i neosjetljivosti na tuđe potrebe (Arnold, 1994.).

Medijski izvještaji pokazuju da su namjerno ozljeđivanje, provociranje, nacionalne i rasne uvrede postale dio sportske svakodnevnice. S obzirom na to da je percipirana legitimnost agresivnoga ponašanja značajan prediktor agresivnih reakcija (Bredemeier, 1985.), veoma je važno utvrditi čimbenike koji su povezani s procjenom stupnja prihvatljivosti određenoga ponašanja. Prema rezultatima dosadašnjih istraživanja, percipirana legitimnost nesportskoga ponašanja u većoj je mjeri zastupljena kod pripadnika muškoga spola (Silva, 1983.), u pozitivnoj je korelaciji s duljinom bavljenja sportom (Silva, 1983.; Ryan i sur., 1990.; Visek i Watson, 2005.), razinom natjecanja (Maxwell i sur., 2008.) te stupnjem zastupljenosti fizičkoga kontakta u sportu (Tucker i Parks, 2001.). Osim toga, utvrđeno je da tolerancija agresivnoga ponašanja u sportu ovisi o normama sredine $u$ okviru koje se ponašanje odvija (Ommundsen i sur., 2003.; Miller i sur., 2005.), pa će tolerancija na agresivno ponašanje biti veća ako takvo ponašanje nije sankcionirano ili nailazi na potporu okoline (Conroy i sur., 2001.). Bredemeierova i Shields (1987.) ističu da sportaši različito procjenjuju stupanj prihvatljivosti agresivnih ponašanja u svakodnevnom životu i u sportskom kontekstu, stoga prilikom istraživanja stupnja tolerancije određenoga ponašanja treba voditi računa o specifičnostima sportskog okruženja.

U navedenim istraživanjima uočena legitimnost nesportskoga ponašanja utvrđivana je raznim mjernim instrumentima, pri čemu se pretežno rabio upitnik Sport Behaviour Inventory - SBI (Conroy i sur., 2001.). Upitnik SBI (Conroy i sur., 2001.) sastoji se od 10 sportskih scenarija u kojima su opisana agresivna ponašanja u nizu sportova, a zadatak sudionika bio je da stupanj legitimnosti svake od opisanih situacija procijeni odgovorima na 12 pitanja. U opise sportskih situacija koje se procjenjuju uključeni su bejzbol, hokej na ledu, hokej na travi, košarka, nogomet i ragbi. S obzirom na to da su bejzbol, hokej na ledu, hokej na travi i ragbi u domaćim medijima slabo zastupljeni, primjena upitnika SBI među hrvat- 
DRUŠ. ISTRAŽ. ZAGREB GOD. 20 (2011) BR. $3(113)$

STR. $771-792$

GREBLO, Z. I SUR. KONSTRUKCIJA... skim sportašima ne bi bila opravdana. Naime, procjene hrvatskih sportaša o legitimnosti nesportskih situacija mogle bi biti iskrivljene zbog nedovoljna poznavanja pravila i strukture igre $\mathrm{u}$ navedenim sportovima. Uz navedeno, upitnik SBI omogućuje procjenu percipirane legitimnosti agresivnoga ponašanja, ali ne i širega spektra nedopuštenih ponašanja u sportskom okruženju. Konačno, spomenuti upitnik sastoji se od 120 pitanja, što ga čini preopsežnim za uključivanje u baterije testova kojima je obuhvaćeno više predmeta mjerenja.

S obzirom na prethodno navedene nedostatke SBI upitnika te manjak odgovarajućih mjernih instrumenata za primjenu na populaciji hrvatskih sportaša, osnovni cilj ovog rada bio je konstruirati upitnik za procjenu percipirane legitimnosti nesportskoga ponašanja. Iako je preliminarna verzija novokonstruiranog upitnika već vrednovana u studijama Greblo i Bosnar (2008.) te Štimec (2009.), provjera mjernih svojstava završne verzije upitnika do sada nije provedena. Stoga je drugi cilj rada bio utvrditi konstruktnu valjanost, pouzdanost i osjetljivost Upitnika percipirane legitimnosti nesportskoga ponašanja (PLNP). Konačno, treći cilj ovoga rada bio je provjeriti relacije percipirane legitimnosti nesportskoga ponašanja sa spolom, sportskim stažem i rangom natjecanja.

\section{METODA}

\section{Postupak istraživanja}

Podaci su prikupljeni 2008. godine (osnovna faza istraživanja) i 2009. godine (test-retest) u sklopu redovitih nastavnih sati na Kineziološkom fakultetu. Razmak između prvoga i ponovljenoga prikupljanja podataka u svrhu utvrđivanja test-retest pouzdanosti iznosio je tjedan dana. Prije ispunjavanja upitnika sudionici su upoznati s ciljem istraživanja. Sudjelovanje u istraživanju bilo je dobrovoljno i anonimno, a sudionicima je naglašeno da u svakom trenutku mogu odustati od daljnjeg ispitivanja. Postupak istraživanja odobrilo je Povjerenstvo za znanstveni rad i etiku Kineziološkoga fakulteta Sveučilišta u Zagrebu.

\section{Uzorak sudionika}

Istraživanje je provedeno na prigodnom uzorku od 251 studenta druge godine Kineziološkoga fakulteta Sveučilišta u Zagrebu. U osnovnoj fazi u istraživanje su uključena 192 sudionika, 35\% žena i $65 \%$ muškaraca prosječne dobi od 20 godina. Od ukupnoga broja prethodno navedenih sudionika njih $89 \%$ bavilo se ili se još aktivno bavi nekim sportom, od čega su najzastupljeniji nogomet $(25 \%)$, rukomet $(20 \%)$, borilački sportovi $(11 \%)$, košarka $(7 \%)$, odbojka $(7 \%)$ te atletika $(5 \%)$. U fazu 
istraživanja provedenu s ciljem utvrđivanja test-retest pouzdanosti upitnika uključeno je 59 sudionika.

\section{Upitnik}

Upitnik percipirane legitimnosti nesportskoga ponašanja PLNP - konstruiran je s ciljem procjene stupnja prihvatljivosti ponašanja koja pripadaju kategorijama fizičke agresije, verbalne agresije i varanja. Završna verzija upitnika sastoji se od 14 čestica, koje opisuju specifična nesportska ponašanja, a zadatak sudionika jest da na Likertovoj skali od 5 stupnjeva ( 1 - potpuno neprihvatljivo, 2 - uglavnom neprihvatljivo, 3 - nisam siguran, 4 - uglavnom prihvatljivo, 5 - potpuno prihvatljivo) procijeni stupanj prihvatljivosti opisanoga ponašanja. Stupanj percipirane legitimnosti nesportskoga ponašanja može se interpretirati analizom odgovora na svaku pojedinu česticu upitnika, rezultatima na podskalama upitnika ili na temelju ukupnoga rezultata. Rezultat na svakoj od tri podskale izračunava se kao aritmetička sredina odgovora na pripadajuće čestice. Podskalu Legitimnost težih prekršaja (LTP) tvore odgovori na čestice $1,8,12$ i 14 . Podskalu Legitimnost lakših prekršaja (LLP) tvore odgovori na čestice 4, 5, 6, 7 i 11. Podskalu Legitimnost verbalne agresije (LVA) tvore odgovori na čestice 2, 3, 9, 10 i 13. Ukupni rezultat, tj. Legitimnost nesportskoga ponašanja (LNP), izračunava se kao aritmetička sredina odgovora na svim česticama. Pritom viši ukupni rezultat, odnosno viši rezultat na pojedinoj podskali ili čestici, upućuje na veći stupanj tolerancije nesportskoga ponašanja. S obzirom na rezultate ranijih istraživanja, prema kojima je važnost natjecanja faktor koji može utjecati na percipiranu legitimnost nesportskoga ponašanja (Maxwell i sur., 2008.), u svrhu provjere mjernih svojstava upitnik je primijenjen s uputom procjene legitimnosti nesportskih ponašanja u kontekstu prijateljske utakmice / natjecanja. Svrha primijenjene upute bila je ujednačavanje predmeta mjerenja kod svih sudionika istraživanja, dok se u budućim primjenama upitnika PLNP jednostavnom izmjenom upute može procijeniti percipirana legitimnost nesportskoga ponašanja i u drugim kontekstima razine i važnosti natjecanja. S obzirom na mogućnost da mjerne karakteristike upitnika PLNP variraju ovisno o kontekstu procjene (npr. prijateljska utakmica / natjecateljska utakmica), dobiveni rezultati i zaključci ovog istraživanja odnose se na verziju PLNP upitnika za kontekst prijateljske utakmice / natjecanja. Upitnik se nalazi u prilogu (Prilog 1).

Upitniku PLNP priključena su pitanja o spolu, duljini sportskoga staža i najvišem rangu natjecanja na kojima su sudionici istraživanja sudjelovali ("školsko natjecanje", "županijsko natjecanje", "natjecanje na državnoj razini" i "međudržavno natjecanje"). 


\section{Metode obradbe podataka}

Konstruktna valjanost upitnika provjerena je komponentnim modelom faktorske analize, pri čemu su upotrijebljeni Cattellov scree-test i Guttman-Kaiserov kriterij za redukciju glavnih komponenata te oblimin rotacija s Kaiserovom normalizacijom. Pri tome je izračunano sljedeće: varijance značajnih glavnih komponenata, postotak ukupne varijance čestica objašnjene značajnim glavnim komponentama te svakim od ekstrahiranih faktora, matrica sklopa i matrica korelacija među faktorima. Povezanost podskala upitnika s oblimin faktorima izražena je Pearsonovim koeficijentima korelacije. Pouzdanost tipa interne konzistencije za podskale i ukupan rezultat upitnika izraženi su Cronbachovom alfom, a test-retest pouzdanosti Pearsonovim koeficijentom korelacije. Za prethodno navedene koeficijente izračunane su i pripadajuće donje granice $95 \%$-tnih intervala procjene u populaciji. Doprinos svake pojedine čestice pouzdanosti pripadajuće podskale i ukupnoga rezultata upitnika izražena je Cronbachovom alfom u slučaju isključivanja te čestice iz analize. Osjetljivost čestica, podskala i ukupnoga rezultata upitnika analizirana je deskriptivnim statističkim parametrima: aritmetičkom sredinom i standardnom devijacijom te mjerama oblika distribucije rezultata: koeficijenta asimetrije i koeficijenta zakrivljenosti distribucije. U svrhu provjere teorijskih pretpostavki o relacijama percipirane legitimnosti nesportskoga ponašanja sa spolom, sportskim stažem i rangom natjecanja, proveden je niz multiplih regresijskih analiza. Pri tome je statistička značajnost koeficijenata multiple determinacije i standardiziranih regresijskih koeficijenata testirana na razini pogreške $\mathrm{p}<0,05$.

\section{REZULTATI I DISKUSIJA}

U ovoj studiji konstruiran je upitnik za procjenu percipirane legitimnosti nesportskoga ponašanja te su utvrđene njegove mjerne karakteristike: konstruktna valjanost, pouzdanost i osjetljivost. Rezultati istraživanja pokazali su da upitnik PLNP ima zadovoljavajuće mjerne karakteristike.

\section{Konstrukcija upitnika}

Prvi korak u konstrukciji upitnika PLNP bio je formiranje čestica koje najbolje opisuju ovaj složeni konstrukt. Pri tome je nesportsko ponašanje definirano kao niz specifičnih ponašanja kojima se krše sportska pravila i načela fair playa, a koja pripadaju kategorijama agresivnoga ponašanja ili varanja.

Po Žužulovu mišljenju (1989.), agresivno je ponašanje svaka reakcija koja je izvedena s namjerom da se drugom nanese šteta ili povreda bilo koje vrste, bez obzira na to je li ta namjera do kraja i realizirana. S ciljem obuhvaćanja što većega 
DRUŠ. ISTRAŽ. ZAGREB GOD. 20 (2011), BR. $3(113)$

STR. $771-792$

GREBLO, Z. I SUR.: KONSTRUKCIJA... raspona nesportskih ponašanja, u upitnik su uvrštene čestice s opisom ponašanja koja pripadaju kategorijama fizičke agresije, verbalne agresije i varanja. Iz kategorije fizičke agresije odabrana su ponašanja koja sadrže jasnu namjeru da se nanese ozljeda te pripadaju kategoriji direktne fizičke agresije ("Fizički obračun u svlačionici nakon što je zbog suigračeve pogreške došlo do poraza") te ponašanja u kojima namjera za fizičkom povredom nije eksplicitno izražena. Ponašanja koja ne sadrže jasnu namjeru za ozljeđivanjem, a ipak rezultiraju ozljedom (najčešće članova protivničke momčadi), u sportu su vrlo česta i u većini slučajeva posljedica su slučajnog ozljeđivanja u žaru igre, odnosno asertivnoga ponašanja sportaša (Conroy i sur., 2001.). Međutim, s obzirom na to da spomenuta ponašanja mogu biti i posljedica instrumentalne agresije, kojoj primarni cilj nije nanošenje ozljede nego ostvarenje nekoga drugog cilja, poput postizanja pogotka (Husman i Silva, 1984.), odlučili smo ih uvrstiti u upitnik. Ponašanja koja ne sadrže jasnu namjeru za nanošenjem ozljede mogu se razlikovati s obzirom na potencijalnu štetnost posljedica tih ponašanja, stoga su u upitnik uvrštene čestice koje mogu rezultirati manjom ili većom slučajnom štetom ("Povlačenje protivnika za dres" i "Guranje protivničkog igrača u skoku").

Verbalno agresivne poruke ugrožavaju psihički integritet osobe prema kojoj su usmjerene te kod nje izazivaju osjećaj postiđenosti, neadekvatnosti i potištenosti (Infante, 1995.). Ponašanja koja pripadaju kategoriji verbalne agresije uvrštena su u upitnik na temelju ranijih istraživanja, kojima je utvrđena visoka učestalost neprimjerenih oblika komunikacije u sportu (Greblo i sur., 2007.). Čestice ove kategorije sadrže opise ponašanja koja mogu biti rezultat trenutačnih nesuglasica među suigračima (npr. "Vikanje na suigrača kad pogriješi"), ali i opise ponašanja koja upućuju na ozbiljnije narušene odnose među članovima tima ("Glasno omalovažavanje stručnosti vlastita trenera za vrijeme loše utakmice"). S obzirom na to da autori na području psihologije sporta sve češće upozoravaju na neadekvatne metode kojima se služe treneri da bi motivirali sportaše, koje $u$ nekim slučajevima graniče s emocionalnim zlostavljanjem (Gervis i Dunn, 2004.), u upitnik je uvrštena i čestica koja ispituje percipiranu legitimnost agresivnih ponašanja trenera ("Trenerovo verbalno ponižavanje igrača za vrijeme utakmice"). Osim čestica koje opisuju način komuniciranja između članova momčadi, u upitnik su uvrštene i čestice koje opisuju verbalnu agresiju usmjerenu prema članovima suparničke ekipe ("Provociranje igrača na protivničkoj klupi uvredljivim komentarima" i "Vrijeđanje trenera suparničke momčadi"). 
DRUŠ. ISTRAŽ. ZAGREB GOD. 20 (2011), BR. $3(113)$

STR. $771-792$

GREBLO, Z. I SUR. KONSTRUKCIJA...
U preglednom radu o obilježjima varanja u sportskom okruženju Preston i Szymanski (2003.) navode kako se svi oblici varanja u sportu mogu svrstati u jednu od dvije nadređene kategorije - varanje s ciljem ostvarivanja pobjede i varanje s ciljem ostvarivanja poraza. Na temelju spomenute kategorizacije, u upitnik su uvrštene čestice koje opisuju nedopuštene načine ostvarivanja pobjede ("Podmićivanje suca" i "Potplaćivanjem protivničkih igrača osigurati pobjedu u važnoj utakmici") ili osobne koristi ("Otkrivanje taktike vlastite momčadi protivniku iz osobnih interesa"). Osim spomenutih ponašanja, za koja su propisane vrlo stroge sankcije, u upitnik su uključene i čestice koje opisuju učestalije oblike varanja s ciljem postizanja prednosti za vrijeme utakmice / natjecanja ("Laganje je li loptica udarila u aut", "Lažno optuživanje protivnika za prekršaj" i "Nepriznavanje krivnje nakon počinjenoga prekršaja").

\section{Konstruktna valjanost upitnika}

Komponentnim modelom faktorske analize, provedenim na 14 čestica upitnika PLNP, utvrđene su 3 značajne glavne komponente prema Guttman-Kaiserovu kriteriju. Cattellov scree-test upućuje na 2 značajne glavne komponente (Grafikon 1). Zbog mogućih nedoumica u određivanju značajnoga broja glavnih komponenata Cattellovim scree-testom, na koje su uputili Zwick i Velicer (1986.), kao i zbog polazne pretpostavke autora o trodimenzionalnoj strukturi ovoga konstrukta, u daljnjim analizama vodili smo se Guttman-Kaiserovim kriterijem, pa su zadržane 3 glavne komponente. Značajnim glavnim komponentama objašnjeno je $60 \%$ ukupne varijance čestica upitnika, od čega prvom glavnom komponentom $37 \%(\lambda=5,20)$, drugom $14 \%(\lambda=2,02)$, a trećom $8 \%(\lambda=1,15)$. Velika varijanca prve glavne komponente može se smatrati argumentom koji govori u prilog jednodimenzionalnoj strukturi percipirane legitimnosti nesportskoga ponašanja. Međutim, neprijeporno je da druga i treća glavna komponenta također u određenoj mjeri pridonose objašnjenju ovoga konstrukta. Na temelju navedenoga predloženo je kompromisno rješenje, tj. ostavljena je mogućnost izračunavanja ukupnoga rezultata na PLNP upitniku, kao i mogućnost izračunavanja rezultata na pojedinim dimenzijama, što je detaljnije objašnjeno u daljnjem tekstu. Neortogonalnom rotacijom značajnih glavnih komponenata (oblimin s Kaiserovom normalizacijom) utvrđena je prilično jednostavna faktorska struktura upitnika, pri čemu je svaki od faktora zasićen podjednakim brojem čestica (Tablica 1). Komunaliteti čestica kretali su se između 0,43 i 0,78 , pri čemu je 12 od ukupno 14 čestica imalo komunalitet veći od 0,5 . S obzirom na prethodno navedene parametre, veličina uzorka mo- 
DRUŠ. ISTRAŽ. ZAGREB GOD. 20 (2011), BR. 3 (113)

STR. 771-792

GREBLO, Z. I SUR.: KONSTRUKCIJA...

- GRAFIKON 1 Varijance glavnih komponenata utvrdene faktorskom analizom čestica Upitnika percipirane legitimnosti nesportskoga ponašanja (Scree plot)

(1) TABLICA 1 Faktorska struktura Upitnika percipirane legitimnosti nesportskoga ponašanja matrica faktorskoga sklopa že se smatrati prikladnom za vjernu procjenu faktorske strukture u populaciji (MacCallum i sur., 1999.).

Paralelne projekcije čestica koje dominantno saturiraju pojedine faktore kretale su se $\mathrm{u}$ rasponu od $0,60 \mathrm{do} 0,90 \mathrm{za}$ prvi faktor, od 0,62 do 0,86 za drugi i od 0,60 do 0,74 za treći faktor (Tablica 1).

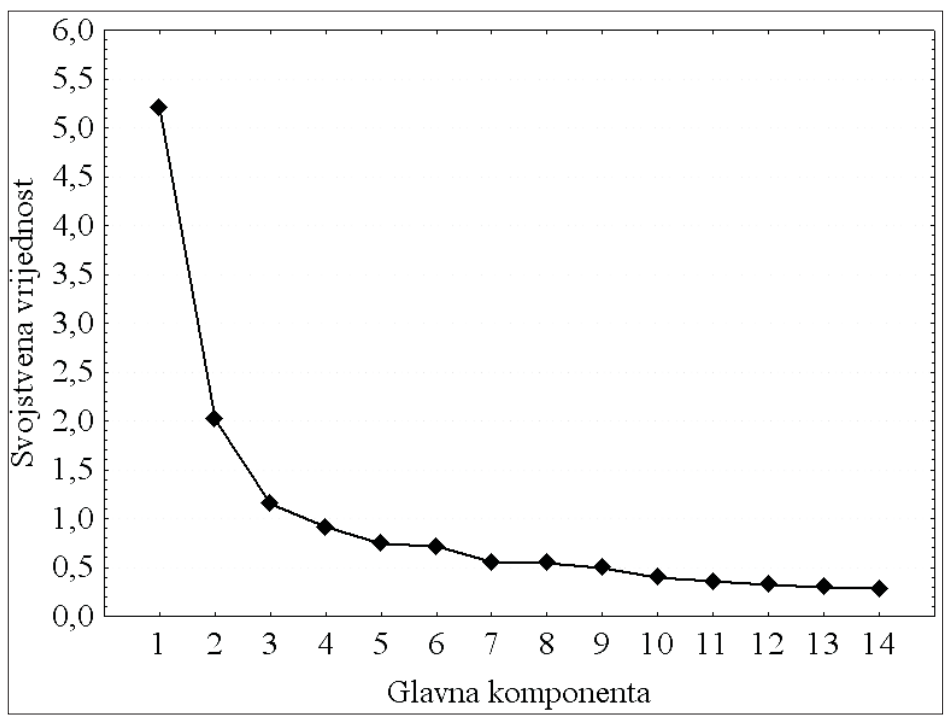

\section{Čestica}

Faktor

1. Otkrivanje taktike vlastite momčadi protivniku

zbog osobnih interesa (npr. zarada)

2. Vikanje na suigrača kad pogriješi

3. Trenerovo verbalno ponižavanje igrača za vrijeme utakmice

4. Lažno optuživanje protivnika za prekršaj

5. Guranje protivničkog igrača u skoku

6. Laganje je li loptica udarila $u$ aut

7. Povlačenje protivnika za dres

8. Potplaćivanjem protivničkih igrača osigurati pobjedu u važnoj utakmici

9. Provociranje igrača na protivničkoj klupi uvredljivim komentarima

10. Vrijeđanje trenera suparničke momčadi

11. Nepriznavanje krivnje nakon počinjenoga prekršaja

12. Fizički obračun u svlačionici nakon što je zbog suigračeve pogreške došlo do poraza

13. Glasno omalovažavanje stručnosti vlastita trenera za vrijeme loše utakmice

14. Podmićivanje suca

$\begin{array}{rrr}0,60 & 0,00 & 0,10 \\ -0,11 & 0,22 & 0,67 \\ -0,05 & -0,05 & 0,74 \\ 0,07 & 0,62 & 0,18 \\ -0,06 & 0,77 & 0,00 \\ 0,16 & 0,70 & 0,06 \\ 0,03 & 0,86 & -0,14 \\ & & \\ 0,87 & 0,07 & -0,08 \\ 0,09 & 0,25 & 0,60 \\ 0,18 & 0,12 & 0,62 \\ -0,05 & 0,76 & 0,13 \\ & & \\ 0,62 & -0,13 & 0,24 \\ & & \\ 0,17 & -0,13 & 0,73 \\ 0,90 & 0,10 & -0,11\end{array}$
tor bile su znatno nižih apsolutnih vrijednosti $(0,00-0,25)$. Iz 
DRUŠ. ISTRAŽ. ZAGREB GOD. 20 (2011) BR. 3 (113),

STR. $771-792$

GREBLO, Z. I SUR.: KONSTRUKCIJA... matrice faktorskoga sklopa također se može uočiti da su sve čestice upitnika imale nizak kompleksitet, odnosno da su bile dominantno zasićene samo jednim faktorom. Prvi faktor dominantno je saturirao čestice: "Otkrivanje taktike vlastite momčadi protivniku zbog osobnih interesa (npr. zarada)", "Potplaćivanjem protivničkih igrača osigurati pobjedu u važnoj utakmici", "Fizički obračun u svlačionici nakon što je zbog suigračeve pogreške došlo do poraza" i "Podmićivanje suca". Drugi faktor dominantno je saturirao čestice: "Lažno optuživanje protivnika za prekršaj", "Guranje protivničkog igrača u skoku", "Laganje je li loptica udarila u aut", "Povlačenje protivnika za dres" i "Nepriznavanje krivnje nakon počinjenoga prekršaja". Treći faktor dominantno je saturirao čestice: "Vikanje na suigrača kad pogriješi", "Trenerovo verbalno ponižavanje igrača za vrijeme utakmice", "Provociranje igrača na protivničkoj klupi uvredljivim komentarima", "Vrijeđanje trenera suparničke momčadi" i "Glasno omalovažavanje stručnosti vlastita trenera za vrijeme loše utakmice". Korelacija prvoga i drugoga faktora iznosila je 0,22 , prvoga i trećega 0,44 , a drugoga i trećega 0,36 . Nakon kosokutne rotacije, prvim faktorom objašnjeno je $24 \%$, a drugim i trećim po $27 \%$ ukupne varijance čestica upitnika.

Rezultati provedene analize pokazali su da sudionici istraživanja nesportsko ponašanje ne doživljavaju kao jedinstven skup nedopuštenih ponašanja, nego da postoji tendencija prema prilično nezavisnoj procjeni triju grupacija nesportskih ponašanja. Legitimnost ponašanja koja opisuju fizičku agresiju i varanje sudionici su procijenili prije svega na temelju jačine prekršaja, što je rezultiralo grupiranjem tvrdnji koje upućuju na ozbiljniji stupanj prekršaja (faktor 1), odnosno grupiranjem opisa ponašanja koja podliježu manjim sankcijama (faktor 2), bez obzira na to pripada li pojedino ponašanje kategoriji fizičke agresije ili varanja. Iako se uz verbalnu i fizičku agresiju varanje može teoretski sagledati kao nezavisna kategorija, Lee i sur. (2007.) upozoravaju kako je riječ o složenom fenomenu koji je teško konceptualno definirati i operacionalizirati, što je jedan od mogućih razloga zbog kojeg nije utvrđen jasan faktor varanja, nego su se čestice grupirale ovisno o percipiranoj težini prekršaja opisanoga ponašanja. U skladu s navedenim, prvi faktor nazvan je Faktor legitimnosti težih prekršaja, a drugi Faktor legitimnosti lakših prekršaja. Faktor legitimnosti težih prekršaja saturira čestice koje opisuju teže oblike varanja te ponašanja koja se odnose na namjerno nanošenje ozljeda. Predviđene sankcije za spomenuta ponašanja kreću se $\mathrm{u}$ rasponu od novčanih kazni preko zabrane natjecanja i isključivanja iz kluba, pa sve do kažnjavanja u skladu s odredbama kaznenoga zakona (Preston i Szymanski, 
DRUŠ. ISTRAŽ. ZAGREB GOD. 20 (2011), BR. $3(113)$

STR. $771-792$

GREBLO, Z. I SUR.: KONSTRUKCIJA...
2003.). Faktor legitimnosti lakših prekršaja saturira čestice koje se odnose na lakše oblike varanja, odnosno ponašanja kojima sportaši nejasne sportske situacije nastoje okrenuti u vlastitu korist. Uz navedeno, Faktor legitimnosti lakših prekršaja saturira i čestice koje opisuju grube fizičke kontakte koji ne sadrže jasnu namjeru za ozljeđivanjem protivnika, no ipak mogu rezultirati ozljedom. S obzirom na to da je u momčadskim sportovima veoma teško razlikovati ponašanja koja pripadaju kategoriji instrumentalne agresije, tj. nesportskom načinu postizanja prednosti, od asertivnih, tj. odlučnih, cilju usmjerenih ponašanja koja u žaru igre mogu dovesti do neželjene povrede protivničkog igrača (Conroy i sur., 2001.), sudionici su u skladu s očekivanjem opisana ponašanja percipirali kao blaže oblike prekršaja. Grupiranje fizički agresivnih ponašanja na faktore težih i lakših oblika prekršaja u skladu je s rezultatima istraživanja prema kojima se u odnosu na instrumentalnu, hostilna agresija procjenjuje kao socijalno nepoželjniji oblik ponašanja (Keeler, 2007.). Čestice koje sadrže opise ponašanja kao što su vikanje na suigrača te vrijeđanje i omalovažavanje članova vlastite ili suparničke ekipe grupirale su se zajedno, neovisno o tome opisuju li blaže ili teže oblike verbalnih napada (faktor 3). U skladu s navedenim, treći faktor nazvan je Faktor legitimnosti verbalne agresije.

U skladu s prethodno opisanom faktorskom strukturom, predloženo je da se rezultat sudionika na pojedinoj podskali upitnika (Legitimnost težih prekršaja, Legitimnost lakših prekršaja i Legitimnost verbalne agresije) izračunava kao aritmetička sredina rezultata na česticama koje dominantno saturiraju odgovarajući, odnosno istoimeni, faktor. Visoke korelacije podskala s odgovarajućim faktorima $(0,98-0,99)$ upućuju na opravdanost ovakva načina izračunavanja podskala.

U prvoj provjeri konstruktne valjanosti preliminarne verzije upitnika na uzorku polaznika trenerskih studija prema Guttman-Kaiserovu kriteriju utvrđeno je 8 značajnih glavnih komponenti (Greblo i Bosnar, 2008.), dok je u ponovljenoj provjeri na uzorku učenika srednje škole prema istom kriteriju utvrđeno 7 značajnih glavnih komponenti (Štimec, 2009.). Veći broj značajnih glavnih komponenata utvrđen provjerom konstruktne valjanosti $u$ prethodno navedenim istraživanjima ne začuđuje, s obzirom na to da je preliminarna verzija upitnika sadržavala 30 čestica. Usporedba konstruktne valjanosti upitnika PLNP s rezultatima faktorske analize preliminarnih verzija upitnika (Greblo i Bosnar, 2008.; Štimec, 2009.) upućuje na jednostavniju, jasniju i semantički interpretabilniju faktorsku strukturu završne verzije upitnika. 


\section{Pouzdanost upitnika}

Pouzdanost podskala i ukupnoga rezultata upitnika, procijenjena metodom interne konzistencije, te pripadajući intervali procjene pouzdanosti u populaciji sudionika prikazani su u Tablici 2.

Cronbachov koeficijent pouzdanosti ukupnoga rezultata upitnika utvrđen na analiziranom uzorku sudionika iznosio je 0,86 , a pripadajuća donja granica $95 \%$-tnog intervala procjene pouzdanosti u populaciji sudionika 0,83 . Interna konzistencija podskala upitnika kretala se između 0,77 za Legitimnost težih prekršaja i 0,83 za Legitimnost lakših prekršaja. Najniža donja granica 95\%-tnog intervala procjene Cronbachova koeficijenta pouzdanosti u populaciji sudionika utvrđena je za podskalu Legitimnost težih prekršaja $(0,72)$. Viša pouzdanost ukupnoga rezultata na upitniku u odnosu na pouzdanost pojedinih skala upitnika ne začuđuje s obzirom na to da se ukupan rezultat izračunava kao jednostavna linearna kombinacija svih 14 čestica, dok se rezultati na podskalama izračunavaju na temelju 4, odnosno 5, čestica. Navedeno je u skladu s postavkama klasične teorije mjerenja, prema kojoj veći broj čestica pridonosi većoj pouzdanosti testa. U istraživanju koje su proveli Miller i sur. (2005.) pouzdanost percipirane legitimnosti namjernih ozljeda u sportu za dva ponuđena scenarija iznosila je 0,86 i 0,88. Pouzdanost mjernog instrumenta Sport Behavior Inventory - SBI, koji omogućuje procjenu percipirane legitimnosti agresivnoga ponašanja, iznosila je 0,97 (Conroy i sur., 2001.). Pretpostavlja se da je niža pouzdanost upitnika PLNP u odnosu na upitnik SBI posljedica različita stupnja složenosti predmeta mjerenja. Naime, upitnik SBI sadrži čestice koje se odnose isključivo na procjenu legitimnosti fi-

(1) TABLICA 2

Pouzdanost podskala i ukupnoga rezultata Upitnika percipirane legitimnosti nesportskoga ponašanja zičke agresije, dok se upitnikom PLNP procjenjuje mnogo širi spektar nesportskoga ponašanja te osim fizičke agresije sadrži i opise ponašanja koji pripadaju kategorijama verbalne agresije i varanja.

\begin{tabular}{lcrrrr}
\hline \multirow{2}{*}{ Podskala } & \multicolumn{2}{c}{ Interna konzistencija } & & Test-retest \\
\cline { 5 - 6 } & Cronbach $\alpha$ & $95 \%$ LCL $^{*}$ & Pearson r & $95 \%$ LCL $^{\dagger}$ \\
\hline Legitimnost težih prekršaja (LTP) & 0,77 & 0,72 & 0,67 & 0,49 \\
Legitimnost lakših prekršaja (LLP) & 0,83 & 0,80 & 0,85 & 0,76 \\
Legitimnost verbalne agresije (LVA) & 0,78 & 0,73 & 0,73 & 0,58 \\
Legitimnost nesportskoga ponašanja (LNP) & 0,86 & 0,83 & 0,81 & 0,71
\end{tabular}

*donja granica 95\%-tnog intervala procjene Cronbachova koeficijenta pouzdanosti u populaciji sudionika; tdonja granica 95\%-tnog intervala procjene Pearsonova koeficijenta korelacije u populaciji sudionika

Pouzdanost u slučaju isključivanja pojedinih čestica kretala se u rasponu od 0,65 do 0,79 za podskalu Legitimnost težih prekršaja, od 0,79 do 0,81 za podskalu Legitimnost lakših 
DRUŠ. ISTRAŽ. ZAGREB GOD. 20 (2011), BR. $3(113)$

STR. 771-792

GREBLO, Z. I SUR.: KONSTRUKCIJA... prekršaja, od 0,71 do 0,77 za podskalu Legitimnost verbalne agresije i od 0,84 do 0,86 za ukupni rezultat upitnika. Rezultati pokazuju da sve čestice upitnika, osim prve - "Otkrivanje taktike vlastite momčadi protivniku zbog osobnih interesa (npr. zarada)" - pridonose povećanju pouzdanosti pojedinih podskala i ukupnoga rezultata upitnika. Unatoč tomu što navedena čestica neznatno narušava pouzdanost podskale Legitimnost težih prekršaja, zadržana je u upitniku jer je jedina koja se sadržajno odnosi na specifičan aspekt varanja u sportu, što su ga opisali Preston i Szymanski (2003.), a kojem je cilj osigurati poraz radi ostvarenja osobne dobiti.

Test-retest pouzdanosti ukupnoga rezultata upitnika iznosila je 0,81 , dok se kod podskala upitnika kretala između 0,67 za Legitimnost težih prekršaja, a 0,85 za Legitimnost lakših prekršaja. Utvrđeni koeficijenti test-retest pouzdanosti upućuju na zadovoljavajuću stabilnost u vremenu za predmet mjerenja pojedinih podskala, kao i cjelokupnog upitnika. $\mathrm{Na}$ temelju svega navedenog može se zaključiti da podskale i ukupni rezultat upitnika PLNP imaju zadovoljavajuću pouzdanost.

\section{Osjetljivost upitnika}

Rezultati analize osjetljivosti upitnika prikazani su u Tablici 3. Najniža aritmetička sredina utvrđena je za česticu "Fizički obračun u svlačionici nakon što je zbog suigračeve pogreške došlo do poraza" $(1,20)$. Opisano ponašanje ne samo što uključuje namjerno nanošenje ozljede koje izaziva moralnu osudu nego narušava i grupnu koheziju momčadi, koja se često ističe kao preduvjet timskog uspjeha (Mullen i Cooper, 1994.). Iako se $\mathrm{u}$ sportu ni hostilna, ni instrumentalna agresija ne bi smjele tolerirati (Husman i Silva, 1984.), Conroy i sur. (2001.) utvrdili su da hostilnu agresiju sportaši procjenjuju manje prihvatljivom $u$ odnosu na instrumentalnu agresiju, na što upućuju i rezultati našeg istraživanja. Osim fizičkoga kažnjavanja suigrača zbog pogreške, sudionici su najmanje prihvatljivima procijenili čestice "Podmićivanje suca" $(1,27)$ i "Potplaćivanjem protivničkih igrača osigurati pobjedu u važnoj utakmici" $(1,28)$. S obzirom na to da je riječ o ponašanjima za koja su u sportu propisane najviše sankcije (Preston i Szymanski, 2003.), procjene koje upućuju na visok stupanj neprihvatljivosti navedenih ponašanja u skladu su s očekivanjima. Najviše prosječne ocjene u smjeru tolerancije ponašanja dobivene su za čestice: "Povlačenje protivnika za dres" $(2,65)$ i "Guranje protivničkog igrača u skoku" $(2,41)$. Navedene tvrdnje odnose se na ponašanja koja ne sadrže jasnu namjeru za nanošenjem ozljede ili povrede te se mogu protumačiti kao posljedica asertivnoga ponašanja (Husman i Silva, 1984.), što 
DRUŠ. ISTRAŽ. ZAGREB GOD. 20 (2011) BR. $3(113)$

STR. $771-792$

GREBLO, Z. I SUR.: KONSTRUKCIJA...

(4) TABLICA 3

Deskriptivni statistički parametri te miere asimetrije i zakrivljenosti distribucija rezultata upitnika može pridonijeti većem stupnju tolerancije za spomenuta ponašanja. Standardne devijacije čestica kretale su se između 0,58 i 1,28, pri čemu je najveća varijabilnost $u$ odgovorima utvrđena za čestice podskale Legitimnost lakših prekršaja $(1,04-1,28)$, zatim za čestice podskale Legitimnost verbalne agresije $(0,65-0,79)$, a najmanja za čestice podskale Legitimnost težih prekršaja $(0,58-0,78)$. Varijabilnost odgovora manja je kod jačih prekršaja, što upućuje na povećanje konsenzusa procjenjivača s povećanjem neprihvatljivosti prekršaja. $\mathrm{U}$ prilog navedenom govori i visoka pozitivna asimetrija distribucija $\left(2,45 \leq \mathrm{a}_{3} \leq 3,45\right)$ i izrazito visoki koeficijenti zakrivljenosti distribucija $\left(5,56 \leq \mathrm{a}_{4} \leq 13,67\right)$ čestica skale Legitimnost težih prekršaja. Iako su takvi rezultati očekivani, niske aritmetičke sredine i standardne devijacije čestica podskale Legitimnost težih prekršaja i većine čestica podskale Legitimnost verbalne agresije upućuju na njihovu nisku osjetljivost.

\begin{tabular}{lrrrrr}
\hline Čestica & $\mathrm{M}$ & $\mathrm{s}$ & $\mathrm{a}_{3}{ }^{*}$ & $\mathrm{a}_{4}{ }^{\dagger}$ \\
\hline 1. Otkrivanje taktike vlastite momčadi protivniku & & & & \\
zbog osobnih interesa (npr. zarada) & 1,35 & 0,78 & 2,45 & 5,56 \\
2. Vikanje na suigrača kad pogriješi & 2,13 & 1,08 & 0,73 & $-0,33$ \\
3. Trenerovo verbalno ponižavanje igrača za vrijeme utakmice & 1,38 & 0,69 & 2,15 & 5,36 \\
4. Lažno optuživanje protivnika za prekršaj & 1,93 & 1,06 & 1,02 & 0,33 \\
5. Guranje protivničkog igrača u skoku & 2,41 & 1,28 & 0,51 & $-0,86$ \\
6. Laganje je li loptica udarila u aut & 2,20 & 1,15 & 0,71 & $-0,29$ \\
7. Povlačenje protivnika za dres & 2,65 & 1,24 & 0,27 & $-0,99$ \\
8. Potplaćivanjem protivničkih igrača osigurati pobjedu & & & & \\
u važnoj utakmici & 1,28 & 0,72 & 2,97 & 8,80 \\
9. Provociranje igrača na protivničkoj klupi & & & & \\
uvredljivim komentarima & 1,48 & 0,79 & 1,68 & 2,10 \\
10. Vrijeđanje trenera suparničke momčadi & 1,37 & 0,76 & 2,28 & 5,06 \\
11. Nepriznavanje krivnje nakon počinjenoga prekršaja & 1,92 & 1,04 & 1,10 & 0,72 \\
12. Fizički obračun u svlačionici nakon što je zbog & & & & \\
suigračeve pogreške došlo do poraza & 1,20 & 0,58 & 3,45 & 13,67 \\
13. Glasno omalovažavanje stručnosti vlastita trenera & & & & \\
za vrijeme loše utakmice & 1,33 & 0,65 & 2,47 & 7,58 \\
14. Podmićivanje suca & 1,27 & 0,66 & 3,02 & 10,06 \\
Legitimnost težih prekršaja (LTP) & 1,27 & 0,53 & 2,69 & 8,32 \\
Legitimnost lakših prekršaja (LLP) & 2,22 & 0,89 & 0,81 & 0,52 \\
Legitimnost verbalne agresije (LVA) & 1,54 & 0,59 & 1,43 & 1,62 \\
Legitimnost nesportskoga ponašanja (LNP) & 1,71 & 0,55 & 1,13 & 1,30 \\
\hline
\end{tabular}

${ }^{*}$ Koeficijent asimetrije distribucije - skewness; †Koeficijent zakrivljenosti distribucije - kurtosis

U skladu s očekivanjem, prosječne vrijednosti rezultata na podskalama, kao i prosječna vrijednost ukupnoga rezultata, također su pomaknute prema nižim vrijednostima, odnosno u smjeru manjega stupnja prihvatljivosti. Najniža aritmetička 
DRUŠ. ISTRAŽ. ZAGREB GOD. 20 (2011), BR. $3(113)$

STR. $771-792$

GREBLO, Z. I SUR.: KONSTRUKCIJA.. sredina i standardna devijacija utvrđene su za podskalu Legitimnost težih prekršaja $(1,27 \pm 0,53)$, zatim za podskalu Legitimnost verbalne agresije $(1,54 \pm 0,59)$, a najviše za podskalu Legitimnost lakših prekršaja $(2,22 \pm 0,89)$. Ukupno gledajući, osjetljivost upitnika PLNP na ovom je uzorku sudionika niska, posebno za čestice podskala i same podskale Legitimnost težih prekršaja i Legitimnost verbalne agresije. Mogući razlog utvrđene niske osjetljivosti upitnika jest što se kod sudionika procjena percipirane legitimnosti nesportskoga ponašanja provodila u kontekstu prijateljske utakmice. U raznim kontekstima procjene (npr. natjecateljski kontekst) može se očekivati viša osjetljivost čestica i podskala upitnika.

\section{Odrednice percipirane legitimnosti nesportskoga ponašanja}

U svrhu boljega razumijevanja predmeta mjerenja, koji se utvrđuju upitnikom PLNP, kao i u svrhu provjere teorijskih pretpostavki o relacijama percipirane legitimnosti nesportskoga ponašanja sa spolom, sportskim stažem i rangom natjecanja, proveden je niz multiplih regresijskih analiza (Tablica 4).

\begin{tabular}{lrrrr}
\hline & \multicolumn{3}{c}{ Prediktorske varijable $(\beta)^{*}$} \\
\cline { 2 - 5 } Kriterijska varijabla & Spol & $\begin{array}{r}\text { Sportski } \\
\text { staž }\end{array}$ & $\begin{array}{c}\text { Rang } \\
\text { natjecanja }\end{array}$ & $\mathrm{R}^{2 \dagger}$ \\
\hline Legitimnost težih prekršaja (LTP) & $-0,26 \ddagger$ & $-0,16 \ddagger$ & 0,05 & $0,08 \ddagger$ \\
Legitimnost lakših prekršaja (LLP) & $-0,26 \ddagger$ & $0,20 \ddagger$ & $-0,06$ & $0,11 \ddagger$ \\
Legitimnost verbalne agresije (LVA) & $-0,29 \ddagger$ & 0,08 & 0,07 & $0,10 \ddagger$ \\
Legitimnost nesportskoga ponašanja (LNP) & $-0,33 \ddagger$ & 0,10 & 0,01 & $0,13 \ddagger$ \\
\hline
\end{tabular}

*Standardizirani regresijski koeficijent prediktorske varijable; †Koeficijent multiple determinacije; $\ddagger \mathrm{p}<0,05$

(1) TABLICA 4

Neke odrednice percipirane legitimnosti nesportskoga ponašanja - rezultati serije multiplih regresijskih analiza
Utvrđena je statistički značajna povezanost spola sa svim podskalama, kao i s ukupnim rezultatom PLNP upitnika, pri čemu veći stupanj prihvatljivosti nesportskoga ponašanja obilježava pripadnike muškoga spola, što je u skladu s rezultatima dosadašnjih istraživanja (Silva, 1983.). Nezavisnost svih podskala i ukupnoga rezultata upitnika od razine natjecanja na kojoj su se sudionici istraživanja natjecali moguća je posljedica konteksta u kojem se provodila procjena legitimnosti nesportskoga ponašanja (prijateljska utakmica / natjecanje), što bi trebalo provjeriti u budućim istraživanjima. U skladu s dosadašnjim nalazima (Silva, 1983.; Ryan i sur., 1990.; Visek i Watson, 2005.), utvrđena je pozitivna veza duljine bavljenja sportom i podskale Legitimnost lakših prekršaja. Negativna veza podskale Legitimnost težih prekršaja i nezavisnost podskale Legitimnost verbalne agresije te ukupnoga rezultata upitnika od sportskoga staža nisu u skladu s rezultatima do- 
DRUŠ. ISTRAŽ. ZAGREB GOD. 20 (2011), BR. 3 (113),

STR. $771-792$

GREBLO, Z. I SUR.: KONSTRUKCIJA... sadašnjih istraživanja. Mogući razlog tomu leži u činjenici da su se u prethodnim istraživanjima odrednice percipirane legitimnosti nesportskoga ponašanja utvrđivale za drugačije populacije ispitanika. U svakom slučaju, različit smjer povezanosti sportskoga staža s pojedinim podskalama upitnika govori $\mathrm{u}$ prilog tomu da percipiranu legitimnost nesportskoga ponašanja $u$ istraživanjima treba tretirati kao višedimenzionalni konstrukt.

\section{Ograničenja istraživanja}

Istraživanje je provedeno na uzorku studenata Kineziološkoga fakulteta u Zagrebu. Kako je riječ o prigodnom uzorku, heterogenom s obzirom na obilježja sportskog iskustva sudionika (vrsta sporta / aktivnosti, razina dostignuća i sl.), rezultati ovog istraživanja ne mogu se s potpunom sigurnosti generalizirati na razne subpopulacije sportaša. $\mathrm{S}$ obzirom na navedeno, $\mathrm{u}$ budućim istraživanjima bilo bi korisno utvrditi mjerne karakteristike PLNP upitnika i na pojedinim subpopulacijama sportaša. Osim toga, treba naglasiti da se mjerne karakteristike upitnika utvrđene $\mathrm{u}$ ovom istraživanju odnose samo na verziju upitnika za kontekst prijateljske utakmice, pa bi u budućim istraživanjima trebalo provjeriti mjerne karakteristike verzije upitnika za kontekst natjecateljske utakmice.

S ciljem jasnijega razumijevanja percipirane legitimnosti nesportskoga ponašanja te utvrđivanja čimbenika povezanih s različitim stupnjem tolerancije lakših i težih oblika prekršaja te verbalne agresije, $u$ budućim istraživanjima upitnik bi uz variranje upute (npr. procjena legitimnosti ponašanja u kontekstu prijateljske ili odlučujuće utakmice / natjecanja) trebalo primijeniti na različitim uzorcima sportaša (različit spol, dobna skupina, vrsta sporta, stupanj uspješnosti i sl.) i trenera (različit stil rukovođenja trenera, ciljna orijentacija i sl.).

\section{ZAKLJUČAK}

Upitnik percipirane legitimnosti nesportskoga ponašanja jest višedimenzionalni upitnik što ga karakterizira jednostavna faktorska struktura i zadovoljavajuće visoka razina pouzdanosti, a to ga čini adekvatnim mjernim instrumentom za procjenu percipirane legitimnosti težih prekršaja, lakših prekršaja i verbalno agresivnih ponašanja u sportskom okruženju. Primjena upitnika na različitim uzorcima u kontekstu širokoga raspona sportskih situacija omogućit će bolje razumijevanje ovoga složenog fenomena te identifikaciju čimbenika povezanih s percipiranom legitimnosti specifičnih oblika nesportskoga ponašanja. 


\section{PRILOG 1}

\section{Upitnik percipirane legitimnosti nesportskoga ponašanja - PLNP}

Upitnik koji se nalazi pred Vama sadrži niz tvrdnji o različitim ponašanjima u sportu. Molimo Vas da za svaku tvrdnju na ljestvici od 1 do 5 procijenite $u$ kojoj je mjeri, prema Vašem mišljenju, opisano ponašanje prihvatljivo ili neprihvatljivo ako je vezano uz PRIJATELJSKU UTAKMICU/NATJECANJE, pri čemu je:

$$
\begin{aligned}
& 1 \text { - potpuno neprihvatljivo } \\
& 2 \text { - uglavnom neprihvatljivo } \\
& 3 \text { - nisam siguran } \\
& 4 \text { - uglavnom prihvatljivo } \\
& 5 \text { - potpuno prihvatljivo }
\end{aligned}
$$

Nemojte previše razmišljati o sadržaju svake tvrdnje, već zaokružite odgovor koji prvi procijenite odgovarajućim! Za svaku tvrdnju zaokružite samo jedan od ponuđenih odgovora!

1. Otkrivanje taktike vlastite momčadi protivniku zbog osobnih interesa (npr. zarada)
$\begin{array}{lllll}1 & 2 & 3 & 4 & 5\end{array}$

2. Vikanje na suigrača kad pogriješi

3. Trenerovo verbalno ponižavanje igrača za vrijeme utakmice

4. Lažno optuživanje protivnika za prekršaj

5. Guranje protivničkog igrača u skoku

6. Laganje je li loptica udarila $\mathrm{u}$ aut

7. Povlačenje protivnika za dres

8. Potplaćivanjem protivničkih igrača osigurati pobjedu u važnoj utakmici

9. Provociranje igrača na protivničkoj klupi uvredljivim komentarima

10. Vrijeđanje trenera suparničke momčadi

11. Nepriznavanje krivnje nakon počinjenoga prekršaja

12. Fizički obračun u svlačionici nakon što je zbog suigračeve pogreške došlo do poraza

13. Glasno omalovažavanje stručnosti vlastita trenera za vrijeme loše utakmice $\quad \begin{array}{llllll}1 & 2 & 3 & 4 & 5\end{array}$ 


\section{APPENDIX 1}

\section{The Questionnaire of Perceived Legitimacy of Unsportsmanlike Conduct - PLUC}

This questionnaire consists of a list of statements about different types of sports behavior. On a scale from 1-5, please evaluate how acceptable you find the behavior from each statement in a FRIENDLY MATCH/COMPETITION:
1 - completely unacceptable
2 - mostly unacceptable
3 - I am not sure
4 - mostly acceptable
5 - completely acceptable

Please do not think too much about the content of each statement, but circle the first answer that applies to you! Circle only one answer for each statement!

1. Disclosing the tactics of one's own team to the opposing team for personal gain (e.g. money).

2. Shouting at team-mates when they make a mistake.

3. Verbal humiliation of players by a coach during the match

4. Falsely accusing an opposing player of committing a foul.

5. Pushing the opposing player during jump.

$\begin{array}{lllll}1 & 2 & 3 & 4 & 5\end{array}$

6. Lying whether the ball was of the play.

$\begin{array}{lllll}1 & 2 & 3 & 4 & 5\end{array}$

7. Pulling an opposing player's jersey.

8. Bribing the opposing player to ensure a victory in an important match.

9. Taunting the opposing player sitting on the bench.

$\begin{array}{lllll}1 & 2 & 3 & 4 & 5\end{array}$

10. Insulting the opposing team's coach.

$\begin{array}{lllll}1 & 2 & 3 & 4 & 5\end{array}$

11. Not admitting guilt after committing a foul.

12. Fighting in the locker room after a team-mate's mistake lead to the team's loss.

13. Loud disparaging remarks on the competency of one's own coach during a bad match. 


\section{LITERATURA}

Arnold, P. J. (1994.), Sport and Moral Education. Journal of Moral Education, 23 (1): 75-90. doi:10.1080/0305724940230106

Begg, D. J., Langley, J. D., Moffit, T. i Marshall, S. W. (1996.), Sports and Delinquency: An Examination of the Deterrence Hypothesis in a Longitudinal Study. British Journal of Sports Medicine, 30 (4): 335-341. doi:10.1136/bjsm.30.4.335

Bredemeier, B. J. (1985.), Moral Reasoning and Perceived Legitimacy of Intentionally Injurious Sports Acts. Journal of Sport Psychology, 7 (2): 110-124.

Bredemeier, B. J. i Shields, D. (1987.), Moral Growth through Physical Activity: A Structural Developmental Approach. U: D. Gould i M. R. Weiss (ur.), Advances in Pediatric Sport Sciences: Vol 2. Behavioral Issues (str. 143-165), Champaign, IL: Human Kinetics.

Conroy, D. E., Silva, J. M., Newcomer, R. R., Walker, B. W. i Johnson, M. S. (2001.), Personal and Participatory Socializers of the Perceived Legitimacy of Aggressive Behavior in Sport. Aggressive Behavior, 27 (6): 405-418. doi:10.1002/ab.1026.abs

Đonlić, V., Marušić Štimac, O. i Smojver-Ažić, S. (2005.), Odgojni aspekti sporta - slika o sebi i problemna ponašanja obzirom na uključenost i uspješnost djece u sportskim aktivnostima, Zbornik radova VI. konferencije o športu Alpe-Jadran (str. 197-204), Zagreb: Ministarstvo znanosti, obrazovanja i športa Republike Hrvatske.

Evans, J. i Roberts, G. C. (1987.), Physical Competence and the Development of Children's Peer Relations. Quest, 39 (1): 23-35.

Fox, K. R. (1988.), The Self-Esteem Complex and Youth Fitness. Quest, 40 (3): 230-246.

Gervis, M. i Dunn, N. (2004.), The Emotional Abuse of Elite Child Athletes by Their Coaches. Child Abuse Review, 13 (3): 215-223. doi:10. 1002/car.843

Greblo, Z. i Bosnar, K. (2008.), Mjerna svojstva skale nesportskog ponašanja na uzorku polaznika trenerskih studija. U: B. Neljak (ur.), Zbornik radova 17. ljetne škole kineziologa Republike Hrvatske (str. 119-124), Zagreb: Hrvatski kineziološki savez.

Greblo, Z., Bosnar, K., Sporiš, G. i Prot, F. (2007.), Izloženost nasilju u sportskim situacijama, Zbornik radova znanstveno-stručnog skupa Psihologija nasilja i zlostavljanja (str. 159-168), Osijek: Sveučilište Josipa Jurja Strossmayera, Filozofski fakultet.

Hastad, D. N., Segrave, J. O., Pangrazi, R. i Peterson, G. (1984.), Youth Sports Participation and Deviant Behavior. Sociology of Sports Journal, 1 (4): 366-373.

Holt, R. I. G., Erotokritou-Mulligan, I. i Sönksen, P. H. (2009.), The History of Doping and Growth Hormone Abuse in Sport. Growth Hormone \& IGF Research, 19 (4): 320-326. doi:10.1016/j.ghir.2009.04.009 Horga, S. (1993.), Psihologija sporta, Zagreb, Fakultet za fizičku kulturu. Husman, B. i Silva, J. (1984.), Aggression: Definitional Considerations. U: J. Silva i R. Weinberg (ur.), Psychological Foundations of Sport (str. 246-260), Human Kinetics. 
DRUŠ. ISTRAŽ. ZAGREB GOD. 20 (2011) BR. $3(113)$

STR. $771-792$

GREBLO, Z. I SUR. KONSTRUKCIJA..
Infante, D. A. (1995.), Teaching Students to Understand and Control Verbal Aggression. Communication Education, 44 (1): 51-63. doi:10.1080/ 03634529509378997

Keeler, L. A. (2007.), The Differences in Sport Aggression, Life Aggression, and Life Assertion among Adult Male and Female Collision, Contact, and Non-Contact Sport Athletes. Journal of Sport Behavior, 30 (1): 57-76.

Lee, M. J., Whitehead, J. i Ntoumanis, N. (2007.), Development of the Attitudes to Moral Decision-Making in Youth Sport Questionnaire (AMDYSQ). Psychology of Sport E Exercise, 8 (3): 369-392. doi:10.1016/ j.psychsport.2006.12.002

MacCallum, R. C., Widaman, K. F., Zhang, S. i Hong, S. (1999.), Sample Size in Factor Analysis. Psychological Methods, 4 (1): 84-99. doi:10.1037// 1082-989X.4.1.84

Maxwell, J. P., Visek, A. J. i Moores, E. (2008.), Anger and Perceived Legitimacy of Aggression in Male Hong Kong Chinese Athletes: Effects of Type of Sport and Level of Competition. Psychology of Sport and Exercise, 10 (2): 289-296.

Miller, B. W., Roberts, G. C. i Ommundsen, Y. (2005.), Effect of Perceived Motivational Climate on Moral Functioning, Team Moral Atmosphere Perceptions, and the Legitimacy of Intentionally Injurious Acts among Competitive Youth Football Players. Psychology of Sport and Exercise, 6 (4): 461-477. doi:10.1016/j.psychsport.2004.04.003

Mullen, B. i Cooper, C. (1994.), The Relation between Group Cohesiveness and Performance: An Integration. Psychological Bulletin, 115 (2): 210-227. doi:10.1037/0033-2909.115.2.210

Ogilvie, B. C. i Tutko, T. A. (1971.), Sport: If You Want to Build Character Try Something Else. Psychology Today, 5 (5):61-63.

Ommundsen, Y., Roberts, G. C., Lemyre, P. N. i Treasure, D. (2003.), Perceived Motivational Climate in Male Youth Soccer: Relations to Social-Moral Functioning, Sportspersonship and Team Norm Perceptions. Psychology of Sport and Exercise, 4 (4): 397-413. doi:10.1016/S14690292(02)00038-9

Preston, I. i Szymanski, S. (2003.), Cheating in Contests. Oxford Review of Economic Policy, 19 (4): 612-624. doi:10.1093/oxrep/19.4.612

Reynolds, M. J. (2000.), A Theoretical Exploration of the Relationship between the Expectations of Sports Coaches and the Physical and Emotional Health of Athletes. Journal of Science and Medicine in Sport, 3 (2): 51-57. doi:10.1016/S1440-2440(00)80069-9

Ryan, K., Williams, J. i Wimer, B. (1990.), Athletic Aggression: Perceived Legitimacy and Behavioral Intentions in Girl's High School Basketball. Journal of Sport and Exercise Psychology, 12 (1): 48-55.

Segrave, J., Moreau, C. i Hastad, D. N. (1985.), An Investigation Into the Relationship between Ice Hockey Participation and Delinquency. Sociology of Sport Journal, 2 (4): 281-298.

Silva, J. M. (1983.), The Perceived Legitimacy of Rule Violating Behavior in Sport. Journal of Sport Psychology, 5: 438-448.

Štimec, B. (2009.), Metrijske karakteristike skale nesportskog ponašanja na uzorku učenika srednje škole. U: B. Neljak (ur.), Zbornik ra- 
DRUŠ. ISTRAŽ. ZAGREB GOD. 20 (2011), BR. $3(113)$

STR. $771-792$

GREBLO, Z. I SUR.: KONSTRUKCIJA... dova 18. ljetne škole kineziologa Republike Hrvatske (str. 244-249), Zagreb: Hrvatski kineziološki savez.

Tucker, L. W. i Parks, J. B. (2001.), Effects of Gender and Sport Type on Intercollegiate Athletes' Perceptions of the Legitimacy of Aggressive Behaviors in Sport. Sociology of Sport Journal, 18 (4): 403-413.

Visek, A. i Watson, J. (2005.), Ice Hockey Players' Legitimacy of Aggression and Professionalization of Attitudes. Sport Psychologist, 19 (2): 178-192.

Zwick, W. R. i Velicer, W. F. (1986.), Comparison of Five Rules for Determining the Number of Components to Retain. Psychological Bulletin, 99 (3): 432-442. doi:10.1037//0033-2909.99.3.432

Žužul, M. (1989.), Agresivno ponašanje - Psihologijska analiza, Zagreb, Radna zajednica republičke konferencije Saveza socijalističke omladine Hrvatske.

\section{Development of a Questionnaire for the Assessment of Perceived Legitimacy of Unsportsmanlike Behavior}

\author{
Zrinka GREBLO, Igor GRUIĆ, Katarina OHNJEC, \\ Ivan SEGEDI, Želiko PEDIŠIĆ \\ Faculty of Kinesiology, Zagreb
}

The aim of this study was to develop a questionnaire for the assessment of perceived legitimacy of unsportsmanlike conduct, to examine its psychometric characteristics and relations with gender, sport experience, and competition level. The questionnaire (PLNP) has 14 items describing physical aggression, verbal aggression and cheating. The participant assesses the acceptability of each type of behavior on a Likert five-point scale. The degree of perceived legitimacy can be obtained on the basis of answers to each questionnaire item, the results on the subscales - Legitimacy of Serious Fouls, Legitimacy of Less Serious Fouls, and Legitimacy of Verbal Aggression - or on the basis of the total result. Psychometric characteristics of the questionnaire were tested on a sample of 251 students of the Faculty of Kinesiology. Principal components factor analysis revealed a simple and semantically interpretable factor structure. Cronbach's reliability coefficients ranged from $0.77-0.86$, while test-retest reliability ranged from 0.67-0.85. Multiple regression analyses revealed different relations of gender, sport experience, and competition level with PLNP subscales. The developed questionnaire showed satisfactory psychometric characteristics and that it can be used for the assessment of perceived legitimacy of serious fouls, less serious fouls, and verbal aggression in sports.

Keywords: unsportsmanlike behavior, sport, aggression, cheating 
DRUŠ. ISTRAŽ. ZAGREB GOD. 20 (2011) BR. $3(113)$

STR. $771-792$

GREBLO, Z. I SUR.: KONSTRUKCIJA...
Erstellung eines Fragebogens zur Einschätzung, inwiefern unsportliches Verhalten als berechtigt wahrgenommen wird

Zrinka GREBLO, Igor GRUIĆ, Katarina OHNJEC, Ivan SEGEDI, Željko PEDIŠIĆ

Fakultät für Sportwissenschaft, Zagreb

Das Ziel dieser Arbeit war, einen Fragebogen zu konstruieren, um einschätzen zu können, inwiefern unter Sportlern unsportliches Verhalten als berechtigt wahrgenommen wird; des Weiteren soll der Fragebogen ermöglichen, die messbaren Merkmale unsportlichen Verhaltens zu ermitteln sowie theoretische Grundvoraussetzungen zum Bezug zwischen wahrgenommener Legitimität unsportlichen Verhaltens einerseits und Geschlechtszugehörigkeit, Dauer der Sportkarriere und Ranglistenposition andererseits zu überprüfen. Der erstellte Fragebogen enthält 14 Komponenten, mit denen spezifische unsportliche, den Kategorien körperliche und verbale Aggression sowie Betrug zugehörende Verhaltensmuster beschrieben werden; es war Aufgabe der Untersuchungsteilnehmer, anhand der Likert-Skala (Stufen 1 bis 5) zu bewerten, inwiefern die beschriebenen Verhaltensmuster akzeptabel seien. Die Stufen der wahrgenommenen Legitimität unsportlichen Verhaltens konnten anhand einer Analyse der zu den einzelnen Komponenten gewonnenen Fragen ermittelt werden, und zwar mittels Aussagen, die zu den Subskalen Berechtigung schwerwiegenderer Vergehen, Berechtigung leichterer Vergehen und Berechtigung verbaler Aggression gemacht wurden, oder aber aufgrund des Gesamtergebnisses. An der Untersuchung nahmen 251 Studenten der Fakultät für Sportwissenschaft in Zagreb teil. Anhand einer Faktorenanalyse mit Komponentenmodell, wobei nach dem GuttmannKaiser'schen Kriterium zur Reduzierung der Hauptkomponentenzahl sowie nach der Oblimin-Rotation verfahren wurde, konnte eine einfache und semantisch interpretationsfähige Faktorenstruktur ermittelt werden. Der Reliabilitäts-Koeffizient nach Cronbach lag bei 0,77-0,86, die Test-Retest-Reliabilität wiederum bei 0,67-0,85. Eine Serie multipler Regressionsanalysen ergab unterschiedliche Beziehungsmuster zwischen Geschlechtszugehörigkeit, Daver der Sportkarriere und Ranglistenposition einerseits und einzelnen Subskalen andererseits. Die Untersuchung erwies, dass der erstellte Fragebogen über befriedigende messbare Eigenschaften verfügt und dass er ohne Weiteres eingesetz† werden kann, um festzustellen, inwiefern unter Sportlern schwere und leichtere Vergehen sowie verbale Übergriffe als berechtigt wahrgenommen werden.

Schlüsselbegriffe: Sport, unsportliches Verhalten, Aggressivität, Betrug 